\title{
COMPUTER SCIENCE TASKS AND TOPICS AS A PART OF ICT CURRICULA IN THE EYES OF PUPILS AND TEACHERS
}

\author{
Jiří VANÍČEK
}

\begin{abstract}
Last years, the trend of reintroducing into teaching of information and communication technology not only topics of digital literacy, but also topics from the basics of computer science is emerging in many countries. Czech national school documents disregards these topics and narrow it to digital literacy and handling with applications and information on the Internet. Consequently, Czech primary and secondary schools in global do not produce people prepared for studying IT subjects at the universities. One of projects how to introduce informatics tasks into schools is a Bebras contest, in Czech Bobřík informatiky. A research among participants of the contest has been realized. His research task was to answer questions how teachers and their students take in computer science problems, whether perceive contest tasks as informatical and which tasks are taken in as easy, difficult or inappropriate. The results show that neither students nor their teachers are not clear which problems are solved by computer science, they take informatics as a work with computer or software handling and mark pure informatical problems as non-informatical. Task in which reading and analyzing the code, understanding different representations and structures of information is necessary are very difficult for students. The questing is arising how well are future IT university studnets are prepared at schools.
\end{abstract}

Key words: ICT education, computer science topics, informatics contest, Beaver of informatics

\section{INFORMATICKÉ ÚLOHY A TÉMATA JAKO SOUČÁST KURIKULA ICT V OČÍCH ŽÁKŮ A UČITELŮ}

\begin{abstract}
V poslední době lze $\mathrm{v}$ řadě zemí pozorovat př́íklon k zavádění informatických témat do školního kurikula výuky informačních a komunikačních technologií. České školské dokumenty dosud tuto oblast spíše upozad’ují a omezují na výuku digitální gramotnosti pomocí uživatelského ovládání aplikací a práce $\mathrm{s}$ informacemi na Internetu. V důsledku pak české základní a střední školství neprodukuje absolventy, kteří by byli připraveni studovat informatické obory na vysokých školách. Jedním z projektů, jak do škol přivést otázky týkající se informatiky, je soutěž Bebras, v české verzi Bobřík informatiky. Mezi účastníky soutěže probíhal výzkum, který měl zodpovědět na otázky, jak žáci a učitelé vnímají informatické problémy, zda respondenti vnímají soutěžní úlohy jako informatické, které úlohy jsou vnímány jako lehké, těžké či nepatřičné. Ukazuje se, že žáci ani jejich učitelé nemají jasno, jaké problémy řeší informatika, informatiku vnímají jako práci s počítačem, př́padně ovládání software, opravdové informatické problémy označují za neinformatické. Také úkoly, v nichž je třeba číst a analyzovat kód, porozumět různým reprezentacím a strukturám informací jsou pro žáky velmi obtížné. Je otázkou, nakolik kvalitně připravuje naše školství budoucí studenty IT.
\end{abstract}

Key words: Didaktika ICT, informatická témata, informatická soutěž, Bobř́ík informatiky

\section{Informatika ve výuce ICT na základních školách}

Výuka počítačů v České republice aktuálně prochází změnami. Nový školský zákon z r. 2004 mimo jiné stanovil, že vzdělávací oblast informační a komunikační technologie je jednou z devíti vzdělávacích oblastí na základních školách [1]. V České republice je tak povinně vyučován předmět informační a komunikační technologie (dále ICT), a to i na 1. stupni ZŠ Počínaje letošním školním rokem bude každý absolvent 1 . stupně ZŠ umět ovládat počítač na základní uživatelské úrovni.

$\mathrm{V}$ posledních letech můžeme ve světě pozorovat jiné změny týkající se informačních technologií, které mají dopad na školské kurikulum. Jde o tendenci opětovně zařazovat do výuky práce s počítačem nejen témata týkající se digitální gramotnosti, ale též témata ze základů informatiky. Již v roce 2003 v USA Tuckerův výbor pro K-12 kurikulum z The Association for Computing Machinery deklaruje, že „mezi cíle informatického kurikula na základních a 
středních školách patří zavedení všech základních informatických pojmů pro všechny studenty, a to od 1. stupně základních škol“" [2]. Stejný zdroj požaduje, aby „před ukončením 5. ročníku bylo u žáků rozvinuto jednoduché porozumění pojmu algoritmus.“"

Nejen v České republice se objevují statistiky poklesu zájmu mládeže o technická témata. Např. dokument OECD z r. 2006 uvádí ,že mezi roky 1990 - 2005 relativně poklesl počet studentů prírodních a technických oborü“ [3]. Na tento trend reagují snahy o podporu prírodních věd ve školách. Se snahou změnit trend odklonu mládeže od technických disciplín souvisí snahy etablovat informatiku (computer science) jako pravou př́rodovědeckou disciplínu. Iniciativa Computing at School pokládá ,informatiku za čtvrtou př́rodní vědu“, protože nám umožňuje „porozumět prírodě a světu novými cestami a protože rychle proniká do ostatních disciplín, ovšem nejen svými možnostmi provádět výpočty, ale zcela novým způsobem uvažování“ [4]. Jestliže tyto argumenty prrijmeme, pak základy informatiky mohou s využitím motivace dané digitálními technologiemi pěstovat $\mathrm{v}$ žákovi vědecké myšlení, stejně jako $\mathrm{v}$ ostatních prírodních vědách.

$\mathrm{Na}$ otázku, ve kterém věku dítěte lze začít vyučovat základy informatiky, stejný zdroj odpovídá „Je zde silná analogie s ostatními př́rodními vědami. Bereme jako samozřejmost, že každý žák by se měl naučit základní pojmy (řekněme) fyziky ve 3. ročníku ZŠ ... Přesně stejný vzorec můžeme aplikovat na informatiku“ [4].

V České republice se základy informatiky $\mathrm{v}$ dokumentech o vzdělávání na 1 . ani 2 . stupni ZŠ neobjevují. Pouze o výuce algoritmizace je v RVP ve vzdělávací oblasti ICT zmínka, že „vzdělávání vede žáka ke schopnosti využívat při interakci s počítačem algoritmické myšlení", ta ovšem není promítnuta do učiva ani očekávaných výstupů [1].

Jiný př́stup najdeme v Británii, kde „vláda nyní podporuje každou dobrou školu, aby nabízela informatiku (computer science) jako součást svého kurikula, a to již od 1 . stupně ZŠ. “ [4]. Na Slovensku jsou informatická témata ve výuce na 1 . stupni zakotvena daleko pevněji, nebot' ,informatika na 1 . stupni ZŠ se skládá $z$ následujících pěti tematických celků: 1 informace kolem nás, 2 komunikace pomocí digitálních technologií, 3 procedury, řešení problémů, algoritmické myšlení, 4 principy fungování digitálních technologií, 5 informační společnost. [5] Z nich minimálně dvě témata jsou orientována $\mathrm{k}$ základům informatiky jako vědního oboru či propedeutice základních informatických pojmů (stejný př́stup můžeme na českých školách vidět např. u matematiky).

Včlánku prezentujeme výsledky několika dílčich výzkumů různé povahy. Pro prehlednost je radíme odděleně, u každého je popsána metodologie, průběh a zjištění.

\section{Postojový dotazník budoucích učitelů informatiky}

Je asi zřejmé, že běžnému učiteli základní školy, který dostal na škole svěřenu ,výuku počítačư a vyučuje ji neaprobovaně, budou podstatně bližší témata ovládání počítače před základy algoritmizace nebo reprezentace informací a jejich struktury. Nás zajímalo, zda lze podobný postoj očekávat i u mladých, budoucích učitelů, kteří studují obor a budou plně kvalifikováni informatiku na ZŠ vyučovat.

$\mathrm{V}$ roce 2011 jsme provedli výzkum mezi budoucími učiteli informatiky pro ZŠ, studenty předposledního ročníku pedagogické fakulty. 26 respondentům byl zadán dotazník, týkající se 25 vyjmenovaných témat ve výuce počítačových technologií:

- výpočty s tabulkami a grafy;

- hromadné zpracování dat, databáze;

- programování, algoritmizace;

- práce $\mathrm{v}$ textovém editoru;

- principy fungování počítače (binární soustava, ukládání a přenos dat, jednotky apod.);

- hardware počítače prakticky;

- autorské právo, právní souvislosti použití sw;

- hardware a software teoreticky;

- práce s robotickými stavebnicemi;

- práce se soubory a složkami;

- práce s bitmapovou grafikou;

- práce s vektorovou grafikou;

- digitální fotografování a úpravy fotografií;

- ochrana počítače, virová problematika;

- digitální video, zvuk, grafika - stahování, ukládání, přehrávání;

- pravidla typografie v textovém editoru;

- rizika Internetu, počítačová kriminalita;

- editace digitálního videa, zvuku;

- reprezentace dat pomocí grafů, diagramů;

- tvorba mentálních map;

- základní správcovství počítače (heslo, účty, složky, úklid na disku, zálohování, instalace); 
- techniky vyhledávání informací;

- obsluha sociálních sítí, Web 2.0;

- historické souvislosti počítačů;

- počítačové hry.

V dotazníku se šestibodovou škálou (od „vůbec ne“ po ,zásadně ano") respondenti vyznačovali své stanovisko, jak důležité je dané téma pro zařazení do výuky. Ve druhé části dotazníku odpovídali opět v šestibodové škále, nakolik se cítí být odborníky v dané oblasti (od „,netuším“" po ,jsem expert").

Ze zpracovaných výsledků uvádíme:

- Mezi nejvíce požadovanými tématy byla práce se soubory a složkami, práce s texty a pravidla typografie (tedy základní témata ovládání počítače).

- Témata, která bychom označili za informatická, byla v ,žebřričku popularity“ spíše $\mathrm{v}$ dolní části, zatímco témata patřící $\mathrm{k}$ digitální gramotnosti v horní části.

- odborníci.
- Témata týkající se multimédií a grafiky jsme $\mathrm{v}$ dotazníku rozdělili na dvě oblasti uživatelskou (stahování, přehrávání) a tvưrčí (editace, tvorba, fotografování). Ve výsledcích se témata, trénující kompetence tvůrčí povahy, umístila svojí důležitostí za kompetencemi „konzumního“ charakteru.

- Učitelé sebe sama vidí jako odborníky $\mathrm{v}$ tématech práce se soubory, s texty, stahování a ukládání videa a zvuků; naproti tomu se za odborníky nepovažují u témat mentální mapy, robotické stavebnice, historie a programování

- Ve výsledcích byla patrná korelace mezi „znalostí tématu“ respondentem a jeho označením za důležité téma. To by znamenalo, že dotazovaní považují za důležitějš́i ta témata, $v$ nichž se cítí jako

\section{Důležitost výuky tématických celků informatiky a ICT na ZŠ v očích budoucích učitelů}

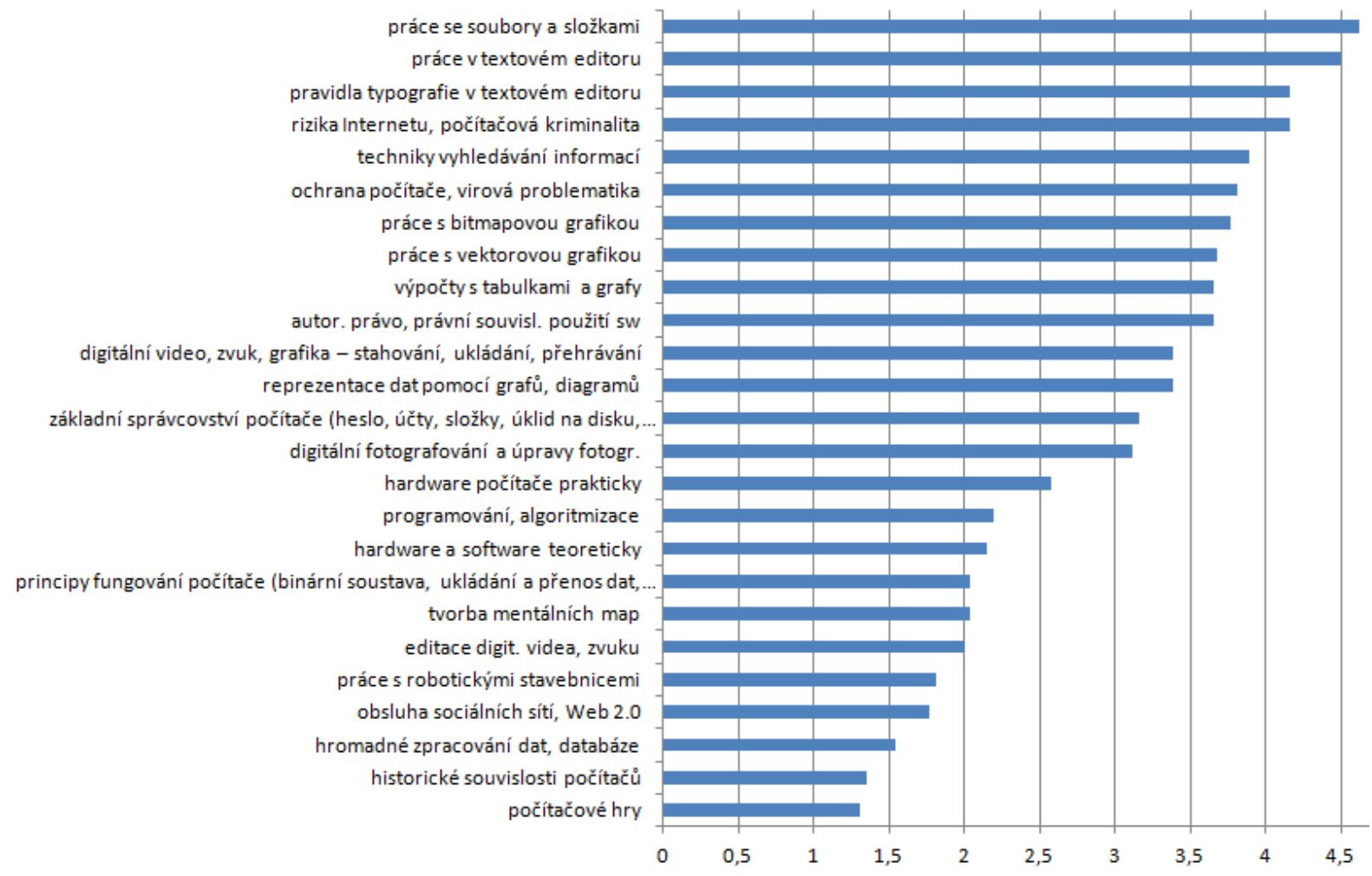

Obr. 1: Tematické celky informatiky a ICT, seřazené podle důležitosti pro výuku podle názoru učitelů 
Informatika a ICT je samožrejmě mladý obor, který bude $\mathrm{k}$ řádnému ukotvení a vymezení svého obsahu ve státních kurikulárních dokumentech ještě potřebovat čas. Nyní je však důležité uvažovat, jaké kompetence má mít absolvent, např. maturant $z$ informatiky. Naše zkušenosti ukazují, že na vysoké školy se na informatické obory hlásí uchazeči, kteří nejen nemají základy oboru, ale ani nebyli školou vybaveni představou o tom, jaké otázky tento obor zkoumá a jaké metody používá. Nemálo uchazečů přichází s představou, že se budou především zabývat ovládáním aplikací. Cílením školní výuky ICT především do oblasti digitální gramotnosti jsou potenciální studenti oboru handicapováni, protože si na rozdíl od matematiky a přírodních věd ze školní výuky při tomto nastavení školního kurikula nemohou udělat představu, jaké povahy je studium informatiky.
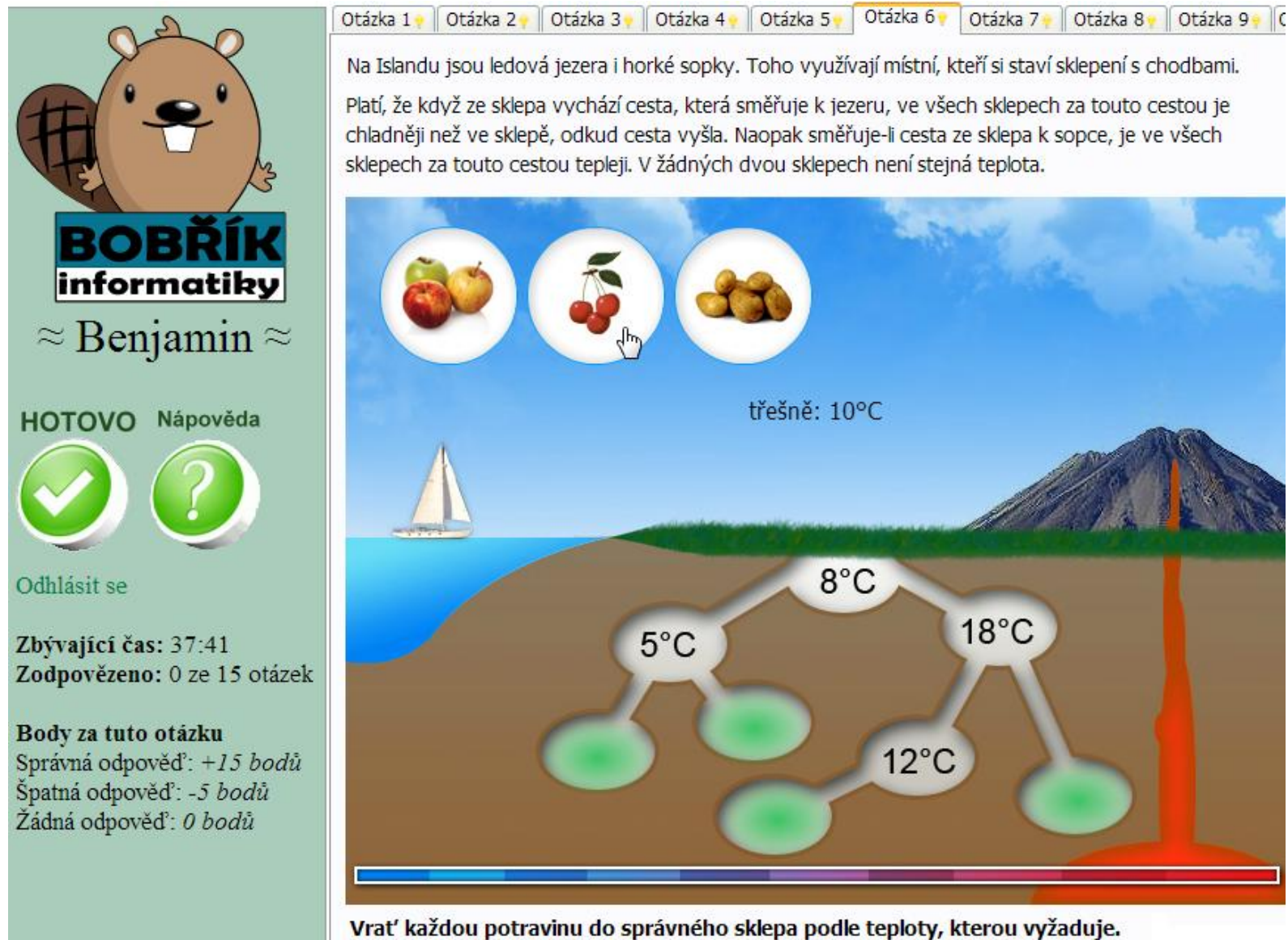

Obr. 2: Bobří informatiky, náhled soutěžniho testu s interaktivní otázkou

\section{Informatická soutěž}

Jako jednu z významných mezinárodních aktivit, která prosazuje větší podíl informatiky v základním a středním školství formou jdoucí mimo školní kurikulum, můžeme zmínit soutěž Bebras (anglicky Beaver of informatics) [6], která je organizována pro žáky základních a středních škol. Soutěž vznikla před devíti lety v Litvě a v České republice se pořádá od r. 2008 a proběhlo dosud pět ročníků. Zájmu o téma soutěže svědčí každoroční značný nárůst počtu zemí i soutěžících v této soutěži. Např. v r. 2012 se soutěžilo v 18 státech Evropy, v Japonsku, v Kanadě a na Tchaj-wanu. [7] V České republice se ve stejném roce zúčastnilo $\mathrm{v}$ pěti věkových kategoriích přes 27000 žáků od 4 . ročníku ZŠ po maturanty. [8]

Soutěž Bobřík informatiky spočivá $\mathrm{v}$ online testu, sestávajícího z 15 otázek z informatiky $\mathrm{s}$ výběrovými odpověd’mi či $\mathrm{s}$ interaktivními zadáními ve formě apletů, v nichž soutěžící myší přmemíst'ují nebo řadí objekty na obrazovce. Je cílena na běžného bystrého žáka se zájmem o počítače, charakterem prŕibuzná Matematickému klokanovi.

Soutěž není zaměřena na informační technologie ani na uživatelský př́stup, preferuje otázky z oblasti základů informatiky, tedy $\mathrm{z}$ 
algoritmizace, porozumění informacím a jejich reprezentacím, řešení problémů a matematických a logických základů informatiky; jedním z témat je digitální gramotnost. Otázky jsou vytvářeny v konsorciu více než 20 zemí, jejichž odborníci na didaktiku informatiky úlohy vymýšlejí, redigují, oponují a národní organizátor pak vybírá ze seznamu takto schválených otázek. Ve speciálně vybraných úlohách, které musí každý stát povinně zařadit do své národní soutěže, se otázky z oblasti uživatelské za poslední roky nevyskytly vůbec.

Domníváme se, že $\mathrm{k}$ atraktivitě soutěže přispívá fakt, že je jedinou masovou školní soutěží realizovanou pomocí počítačů, je interaktivní, poskytuje soutěžícím velmi rychlou zpětnou vazbu, podrobně komentuje všechny chyby, které soutěžící udělal, vysvětluje správné odpovědi. Soutěž také př́liš nezatěžuje administrativu školy (pokud si odmyslíme změny v školním rozvrhu kvůli uvolnění počítačových učeben).

Již zpočátku organizátoři stanovili jeden $\mathrm{z}$ cílů soutěže Bobřík informatiky řekněme osvětový, „ukázat žákům a také jejich učitelům šíri informatické problematiky, která bývá často $\mathrm{v}$ kurikulu jednotlivých škol zužována na informační gramotnost" [9], tedy přinést žákům škol a jejich učitelům informatické otázky, kterým se školní výuka př́liš nebo zcela nevěnuje. Za tím účelem byly ke komentár̆ům ke správným odpovědím jednotlivých úloh přidány vysvětlující texty, co má daná otázka společného $\mathrm{s}$ informatikou. Na webu soutěže byl vytvořen archiv soutěžních testů $\mathrm{s}$ volným prístupem, $\mathrm{v}$ němž je možno vyhledat libovolný soutěžní test $\mathrm{z}$ minulých let a „zahrát si ho“ se vším komfortem ostré soutěže. Testové otázky tak mohou sloužit tréninku na vlastní soutěž i $\mathrm{k}$ výuce ve škole. Znění všech otázek, odkazovaných či citovaných $\mathrm{v}$ tomto článku, lze dohledat $\mathrm{v}$ archivu soutěže na webu soutěže na adrese www.ibobr.cz.

\section{Dotazník směřovaný $k$ učitelům}

Na setkáních organizátorů soutěže s učiteli se projevil zájem učitelů o soutěžní otázky informatické povahy. Nebylo ovšem zřejmé, jestli tyto otázky vnímají jako směrodatné pro výuku, zda mohou změnit nazírání žáků i učitelů na to, co to jsou informatické otázky a problémy, tedy co je také informatika. $\mathrm{K}$ ověření posloužil elektronický dotazník pro školní koordinátory soutěže, tedy pro učitele, kteří na svých školách soutěž organizují. Učitelé byli osloveni v prosinci 2011 třemi otázkami s výběrovými odpověd'mi, týkajícími se využívání soutěžních úloh mimo soutěž a postoje učitelů $\mathrm{k}$ těmto otázkám.

Dotazník vyplnilo 104 školních koordinátorů, tedy téměř polovina všech, kteří se soutěže zúčastnili. Na otázku, nakolik využivají ve výuce komentáře $\mathrm{k}$ otázkám, proč je otázka informatická, $46 \%$ respondentů odpovědělo, že komentáře využívá ve své výuce, a to bud' individuálně $\mathrm{s}$ jednotlivými žáky, nebo hromadným procházením otázek $\mathrm{s}$ celou trídou. $57 \%$ dotazovaných učitelů odpovědělo, že využívá archiv soutěže se soutěžními testy $\mathrm{z}$ minulých let ve své výuce, a to jak $\mathrm{k}$ přípravě žáků na národní kolo soutěže, tak při řádné výuce informatiky (23\% odpovědí). Tedy více než $10 \%$ zúčastněných škol použivá soutěžní otázky při výuce informatiky.

Klíčovou byla otázka, jaký postoj zaujímají učitelé k soutěžním otázkám. Respondenti mohli vybírat mezi šesti variantami odpovědí, z nichž poslední tři, uvedené $\mathrm{v}$ seznamu níže, byly vyhodnoceny jako nesouhlasné:

- nemám s nimi problém (odpověd' vybralo $41 \%$ respondentů)

- jsem rád, že si mohu svoji představu o informatických otázkách porovnat s představou jiných odborníků (18\%)

- poté, co se tyto otázky objevily, jsem upravil svoji výuku tak, že také ukazují žákům, že i toto je informatika (12\%)

- otázky by podle mého názoru měly být více směřovány do konkrétních aplikací a činností na počítači ( $8 \%)$

- žáci by uvítali více otázek z počítačového prostředí $(15 \%)$

- otázky mi vůbec nepřipadají informatické, spíše matematické, logické (6\%)

$\mathrm{Z}$ odpovědí vyplývá, že téměř $30 \%$ učitelů považuje informatické otázky, vybrané mezinárodním týmem odborníků na didaktiku informatiky, jako nějakým způsobem neinformatické (at' již vyslovili svůj názor nebo se skryli za „vyjádření svých žákư“). To podtrhují některé výpovědi dotazovaných $\mathrm{v}$ otázce, co by na soutěži zlepšili, napřs. ,žáci si v po skončení testování nejvíce stěžovali na otázky, které se nevěnovaly problematice informatiky, ale daleko více logiky“.

$\mathrm{Na}$ druhou stranu, většina učitelů se nechá ovlivnit a $12 \%$ respondentů, kteří po zkušenosti se soutěží sami změnili svoji výuku, je potěšitelný počet. 


\section{Analýza soutěžních odpovědí a dotazník pro soutěžící}

Data z průběhu online soutěžení jsou ukládána do databáze a poskytují tak bohatý materiál ke zkoumání, které typy otázek soutěžícím vyhovují a které jsou naopak velmi těžké. Chyběl však srovnávací prvek, jak takovou obtížnost úloh vnímají sami soutěžící. Proto byl v listopadu 2012 vytvořen dotazník pro soutěžící. Ti mohli dobrovolně ( $\mathrm{v}$ závislosti na čase, který jim při výuce po soutěžním testu zbýval) bezprostředně po absolvování soutěže volně komentovat soutěž. Ve čtyřech otázkách pak vybírali, které ze soutěžních otázek jim připadaly nejtěžší či nejlehčí, nejzajímavější a nejméně zajímavé, a odpovídali na otázku, který typ otázek z pohledu formy odpovídání preferují. $\mathrm{Na}$ dotazník odpovědělo $13 \%$ soutěžících. Závěry je třeba brát $\mathrm{s}$ jistou rezervou, protože tyto výpovědi byly porovnávány se soutěžními odpověd'mi, které poskytlo $100 \%$ soutěžících, i když počet vyplněných dotazníků v jednotlivých kategoriích představuje několik stovek respondentů.

Srovnáním výpovědí respondentů o náročnosti a oblíbenosti jednotlivých otázek se skutečně zjištěnou úspěšností jsme mohli posuzovat, nakolik žáci sami rozeznají, které otázky jsou nejtěžší, a zda spojují obtížnost otázky s její atraktivitou (tedy zda označují nejtěžší otázku jako nejzajímavější či nejméně zajímavou).

\section{Obtížnost otázek}

Ve stř̌edoškolských kategoriích byly jako nejtěžší označovány otázky Analýza DNA, Jak vybrat medián, Digitální displej a Změna ukazatelů, tedy otázky, kde se vyskytuje kód, nějaký formální zápis. U kategorií 2 . stupně ZŠ byly mezi nejtěžšími otázky, které slovně neb graficky popisovaly nějaká pravidla nebo procesy a měly delší zadání.

Na obr. 3 je porovnána tzv. pocitová obtížnost otázek se skutečnou $\mathrm{v}$ nejstarší kategorii. Porovnává se tu, kolik respondentů dotazníku označilo danou otázku za nejlehčí, s počtem úspěšných řešitelů této otázky. Vzhledem $\mathrm{k}$ různým počtům soutěžících a odpovídajících $\mathrm{v}$ testu mají svislé osy obou datových řad odlišná měřítka a jsou nesouměřitelné, nicméně $\mathrm{z}$ grafu lze vyčíst mezi oběma obtížnostmi u jednotlivých otázek poměrně malou závislost. Výběr pětice nejlehčích otázek (s nejvyššími hodnotami v grafu) však u obou typů obtížnosti souhlasí.

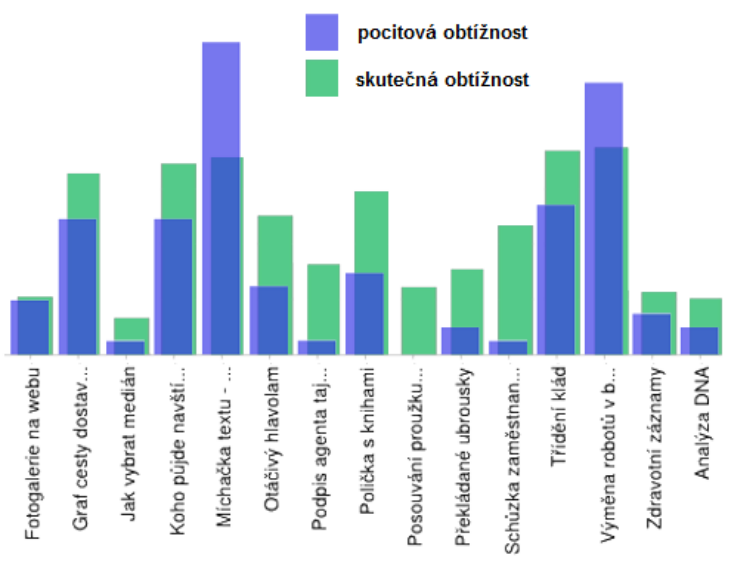

Obr. 3: Pocitová a skutečná obtižnost otázek kategorie Senior ukazuje, že dojem soutěžicího zobtižné otázky ne vždy odpovidá skutečným výsledkům testu

V odpovědích středoškoláků neplatilo, že otázky označené jako nejtěžší měly ve skutečnosti také nejmenší úspěšnost. Ovšem otázky označené jako nejtěžší velmi dobře odpovídaly otázkám, kterým se vyhnulo nejvíce soutěžících. Výjimku zde tvořily interaktivní otázky, které zřejmě sváděly $\mathrm{k}$ tomu začít je řešit, i když se nakonec ukázaly jako těžké.

Porovnávali jsme, zda má obtížnost otázky nějaký vztah $\mathrm{k}$ atraktivitě, tedy zda je vnímána jako zajímavá. Nejtěžší otázku označovali žáci jako nejnudnější asi 2,5krát častěji než jako nejzajímavější. Jak vyplývá z obr. 4, vztah mezi nejzajímavější a nejlehčí otázkou není nijak silný. Daleko více je patrná oblíbenost interaktivních otázek, obě interaktivní jsou mezi čtyřmi nejzajímavějšími, ale nikoliv mezi nejlehčími.

Provedli jsme také analýzu nejobtížnějších otázek podle skutečné úspěšnosti soutěžících, kdy jsme měli $\mathrm{k}$ dispozici počty zvolených nesprávných odpovědí a podle typu chyby, ke které daná nesprávná odpověd' směřovala, mohli určit její prŕčinu. Na základě provedené analýzy jsme mohli roztrí́dit chyby při řešení otázek na:

1. chyby spojené se zvolenou testovací metodou (otázky s výběrovými odpověd’mi $\mathrm{s}$ jedinou odpovědí správnou):

- nekontrolování všech odpovědí

- tipování podle toho, která odpověd' je nejméně odlišná od tř́i ostatních

- nepozorné čtení nebo prohlížení zadání

- předpoklad, že ,ani jedna z ostatních možností není správná“ nemůže být správná odpověd'

2. chyby spojené s testovaným obsahem

- obtížnost čtení kódů, diagramů, grafů

- problémy s logickými otázkami 


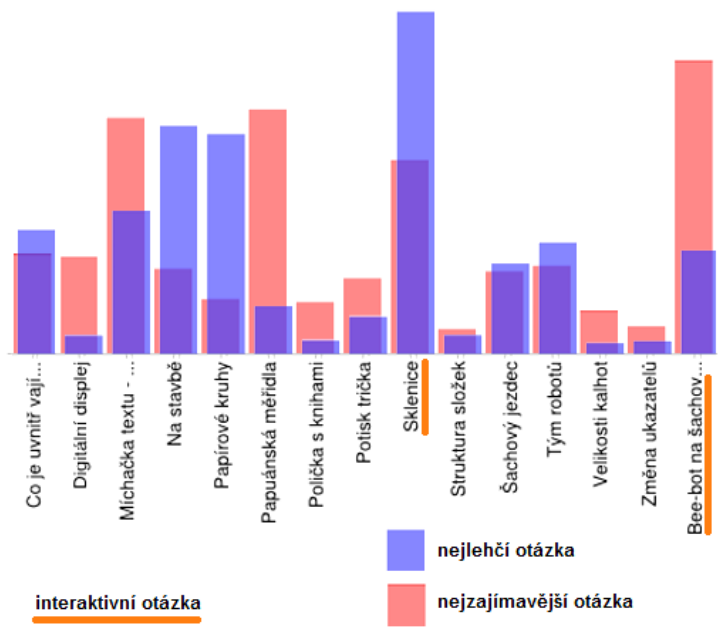

Obr. 4: Porovnání počtu nejzajímavějšich a nejlehčich otázek kategorie Junior v dotazniku

\section{Interaktivita otázek}

U všech kategorií s výjimkou kategorie Junior pro věk 16 - 17 let respondenti vypovídali, že preferují interaktivní otázky před otázkami $\mathrm{s}$ výběrovými odpověd'mi (viz obr. 5). Žáci rádi manipulují objekty, přičemž patrně snadněji objevují, co je v zadání sděleno, na co se otázka ptá a jaký je „prríběh“ a prostředí otázky. Pochopení zadání otázky z psaného textu a obrázků jim zřejmě připadá obtížnější.

Samotná oblíbenost a úspěšnost $v$ řešení interaktivních otázek spolu nesouvisela, protože byly vytvářeny i velmi obtížné interaktivní otázky, které někteří žáci řešili metodou pokus omyl a strávili s ní mnoho času a třeba byli neúspěšní, ale samotná činnost je bavila. Je obtížné na jedné otázce porovnat, zdali větší interaktivita přináší lepší výsledky, protože je problematické sestavit dvě varianty téže otázky tak, aby byla obtížnost textové a interaktivní varianty srovnatelná.

Pokusili jsme se u otázky Sklepy na Islandu (obr. 1) na téma stromového grafu vytvořit jak interaktivní verzi, kdy žáci přiřazovali objekty do sklepů podle popsaných pravidel, tak verzi s výběrovými odpověd'mi, kde žáci vybrali teplotu, pro kterou není vytvořen žádný sklep. Zatímco interaktivní verze v kategorii 6 . - 7. trríd ZŠ patřila mezi průměrně těžké otázky, byla označena za nejzajímavější. Její neinteraktivní verze v kategorii pro $8 .-9$. tř́́dy byla označena za druhou nejtěšší a za průměrně zajímavou. I tento jeden konkrétní př́iklad nevybočil z obecné představy.

\section{Jak žáci vnímali, co je informatika}

Ve volných odpovědích dotazníku, kdy nebyla dána žádná navozující otázka, žáci nejčastěji hodnotili soutěž kladnými nebo zápornými hodnoceními bez vysvětlení (např̀. „Bilo to bezva jste doopravdy husty“, „mega hrozne“). Část komentovala vlastní výkon nebo se vyjadřovala či dotazovala $\mathrm{k}$ jednotlivým otázkám. Nemalá část respondentů především ze středních škol však potřebovala vyjádřit názor, že jim soutěž nepřipadá informatická:

- „Toto nebyla Informatika!!!“,

- "Více otázek z informatiky“,

- „Zaměřil bych otázky více na obor IT. Otázky se mi zdají více matematické",

- „Jen mě zajímá jak tohle souvisí s informatikou, krom toho, že se to vypracovává online a 2 otázky souvisejí s počítačema“,

- „Co mají otázky $\mathrm{v}$ testu společného s informatikou ? že by nic?",

- „Zpracování na počítači nedělá z testu informatickou soutěž “...)

Je potřeba podotknout, že otázky do soutěže procházejí důkladným oponentním řízením v mezinárodní komisi a jsou připravovány didaktiky informatiky $\mathrm{z}$ r̆ady evropských univerzit. Otázky ze stejné databáze používají všechny zúčastněné státy. Můžeme zaručit, že se opravdu jedná o informatické problémy, které se v otázkách řeší.

Velká většina soutěžících vyjádřila svůj názor ještě před zveřejněním komentářů, takže nečetla, proč jsou otázky informatické. $Z$ části výpovědí vyplývá, že žáci se domnívají, že soutěž je organizátory nazývána informatická proto, že se provádí na počítači, a tedy dokážou oddělit informatiku a počítače. Nicméně ukazuje se, že bud'to jsou informatické otázky, předkládané $\mathrm{v}$ této soutěži, umělé a vzdálené běžnému životu, nebo žáci ve škole nezískají správnou představu o tom, co je to informatika, jaké jsou její základní pojmy a jaké řeší problémy. Druhé možné vysvětlení je v tom, že žáci nejsou zvyklí řešit při práci s počítačem náročné problémy, kde je potřeba použít uvažování, logiku, rozhodovat se, formalizovat svoji výpověd', že žáci při pouhém ovládání aplikací se $\mathrm{k}$ takovýmto problémům nedostanou, a potom úlohy $\mathrm{k}$ přemýšlení označují jako matematiku nebo logiku. 


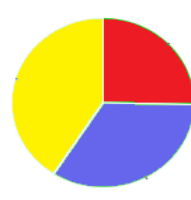

Mini

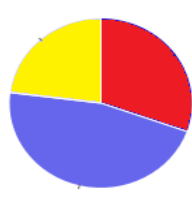

Benjamin

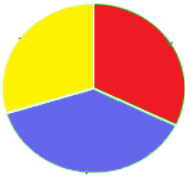

Kadet

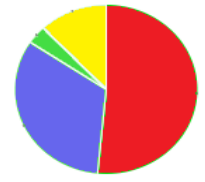

Junior

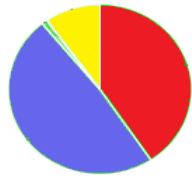

Senior

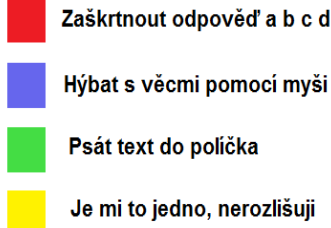

Obr. 5: Preference typů odpovědí v jednotlivých věkových kategoriích

\section{Závěry}

Výsledky výzkumu ukázaly, že soutěž, která přináší ryze informatické otázky, je částí českých učitelů a žáků označována za neinformatickou. To koresponduje s orientací vzdělávací oblasti ICT na ovládání aplikací s odklonem od základů informatiky. Jestliže potřebujeme, aby naše školství připravovalo žáky na vysokoškolská studia informačních technologií, aby je naučilo „,informaticky myslet", nemůžeme setrvávat nastavení tohoto oboru jako tréninku digitální gramotnosti a uživatelského př́stupu $\mathrm{k}$ technologiím u celé populace.

Soutěž jako Bobřík informatiky má potenciál přednést informatická témata do škol a nabízí prostor třeba při přípravě budoucích učitelů informatiky (a všech učitelů 1. stupně, kteři mají povinně základy ICT vyučovat) na fakultách připravujících učitele.

Na druhou stranu, jestliže potřebujeme zvýšit důvěru současných žáků středních škol $\mathrm{v}$ tuto soutěž, budou organizátoři muset více zařazovat otázky z oblastí, které budou více připomínat počítače. Bude to obtížné proto, že $\mathrm{v}$ ostatních zemích pořádajících tuto soutěž takto neuvažují a takové otázky nevytvářejí. Pak se budeme muset vyhnout riziku zařazovat otázky pamětní a faktografické či otázky, které se týkají konkrétní platformy.

\section{Literatura}

[1] Kol. Rámcový vzdělávací program pro základni vzdélávání. Praha: VÚP, 2007.

[2] TUCKER, A. A Model Curriculum for K-12 Computer Science: Final Report of the ACM
K-12 Task Force Curriculum Committee. New York: The Association for Computing Machinery, 2003.

[3] OECD. Evolution of student interest in science and technology studies. Paris: Organisation for Economic Co-operation and Development, Global Science Forum, 2006

[4] Computer Science as a school subject. Seizing the opportunity (online). Computing at School Working Group [cit. 2012-10-24] URL: $<$ http://academy.bcs.org/upload/pdf/cs-schoolsubject.pdf>

[5] BLAHO, A., SALANCI, L. Informatics in Primary School: Principles and Experience. In Kalaš, I. and Mittermeid, R.T. (eds.) ISSEP 2011, s. 129-142, 2011

[6] DAGIENE, V. Sustaining Informatics Education by Contests. In Hromkovič, J., Královič, R. and Vahrenhold, J. (eds.) ISSEP 2010, s. 1 - 12, 2010

[7] Bebras, mezinárodní web informatické soutěže (online). [cit. 2013-01-13] URL: <http://www.bebras.org/countries>

[8] Bobrrík informatiky, web soutěže (online). [cit. 2013-01-10] URL: 〈http://www.ibobr.cz>
doc. PaedDr. Jiří Vaníček, Ph.D.
Katedra informatiky
Pedagogická fakulta Jihočeské univerzity
Jeronýmova 10
371 15, České Budějovice, ČR
Tel: +420 387773074
E-mail: vanicek@pf.jcu.cz
Www pracoviště: wvc.pf.jcu.cz/k 